Article

\title{
Post-Colonial Urban Development and Planning in Cyprus: Shifting Visions and Realities of Early Suburbia
}

\author{
Byron loannou \\ Department of Architecture, School of Engineering, Frederick University, 1036 Nicosia, Cyprus; \\ E-Mail: b.ioannou@frederick.ac.cy
}

Submitted: 14 September 2016 | Accepted: 27 November 2016 | Published: 23 December 2016

\begin{abstract}
The paper studies the evolution of early suburban neighbourhoods in the context of post-colonial urban development and planning. The Planning Report of the colonial Government of Cyprus in 1959 examined the foundations of urban development in Cyprus and at the same time put forward a surprisingly sustainable vision for the future of planning. Despite these early intentions and guidance, urban districts developed in a way that is far from sustainable, according to widely accepted criteria and indicators (participation, effectiveness of planning and development control, sprawl, character and identity, green spaces). The basic hypothesis is that planning has proved insufficiently capable of providing rational urban development. The paper outlines the roots of the planning shortcomings over the last fifty years. British perceptions of planning from the first half of the 20th century influenced the 1959 Report, which affected, in turn, the legislation which followed. Reasons are given as to why development constraints and land market restrictions have prevented the implementation of rational key ideas and sustainable visions throughout the years. The paper concludes by attempting to visualize these dynamic processes in early suburban neighbourhoods and measures distortions of densities, green spaces, and layouts by taking an early suburban district as a case study.
\end{abstract}

\section{Keywords}

city expansion; development control; land speculation; neighbourhood layout; suburban development; urban densities; urban sprawl

\section{Issue}

This article is part of the issue "Paradigm Shifts in Urban Planning", edited by Matthias Drilling (University of Applied Sciences and Arts Northwestern Switzerland, Switzerland), Efrat Eizenberg (Israel Institute of Technology, Israel), Janet Stanley (University of Melbourne, Australia), Lee Boon Thong (Nilai University, Malaysia) and Andreas Wesener (Lincoln University Canterbury, New Zealand).

(C) 2016 by the author; licensee Cogitatio (Lisbon, Portugal). This article is licensed under a Creative Commons Attribution 4.0 International License (CC BY).

\section{Introduction}

The aim of the paper is to investigate the evolution of early suburban neighbourhoods in the context of postcolonial urban development and planning in Cyprus. A parallel goal is to codify the type of economic interests or neoliberal practices applied in this context.

During the first half of the 20th century, the British Colony of Cyprus was a rural economy in which more than $70 \%$ of the population was settled in small rural communities (Morris, 1959). The beginning of the suburban expansion of the existing towns began before the
Second World War without any structured legal framework or regulation in place. The colonial vision of spatial development was unable to depart from the philosophy of international development, which favours growth no matter what the ecological, social or geopolitical consequences (Harvey, 2001, p. 121).

Is it valid to discuss the neoliberal foundations of planning at the European periphery in the mid- $20^{\text {th }}$ century? Neoliberalism is a broad term that encompasses a multitude of different emphases and positions that aim at the dominance of a free market over other common values. Central planning interferes with the market, re- 
duces personal liberty, and undermines the rule of law by creating discretion within the state apparatus. For various reasons, planning undertaken at a local level is usually closer to the interests of the market (Allmendinger, 2009). Neoliberal views accept that some form of control of land use may be centrally coordinated, but only in order to help rather than hinder the market. In the context of a distinct division between society and the investor, the state sacrifices urban commons, such as space and spatial resources, in order to benefit the real estate market and capital accumulation. If planning is a type of regulation, neoliberal deregulation occurs where regulated societies exist (Allmendinger, 2009). What happens in the case of unregulated, transformational societies at the periphery?

The research starts with a background examination of the original British planning system on the island, followed by a description of the Planning Report of 1959 and the socioeconomic conditions of the post-colonial period. Recent planning documentation is used in order to highlight the weaknesses of planning practice at the neighbourhood scale. Pallouriotissa district, an early suburb of Nicosia, is chosen as a case study in order to illustrate the planning output and the evolution of development on the microscale of the local suburban block.

Sustainable Urbanisms is today a basic critical framework, which can test how far urban common lands and other spatial resources are considered of benefit to the developer or local communities. The 'sustainable neighbourhood', a concept defined (and quantified) differently by various scholars (Drilling, 2013; Farr, 2011), forms a good basis for assessing post-colonial neighbourhood development. Basic elements of a 'good neighbourhood' include the presence of environmental and social amenities, optimum densities and a responsive layout, distinct character and identity, and sufficient green spaces. A participatory process in the transformation of places is also seen as part of the sustainable performance of place (Healy, 2010). These parameters can only be regulated through statutory regulation, and thus set and managed by the public sector.

Substantiation by research and quantitative data has gradually been abandoned in official planning documents on urban development in Cyprus following the 1959 Planning Report. The paper attempts to overcome this lack of detailed and up-to-date spatial data firstly by 'decoding' planning documents. The second step is to examine in more detail the microscale of the suburban block and describe indicative features of a purposefully selected case study sample. The focus is on an early suburban district of Nicosia, which records in its built fabric almost all the shifts of the sixty-year period.

How have the other crucial issues, highlighted by the Report, evolved over the sixty years? In Chapter 4 the paper examines briefly the following themes: (i) participatory and democratic planning-planning authorities and local powers, (ii) city expansion, urban sprawl, and "overparcellation", (iii) taxation, betterment levy, and regula- tion of the free real estate market, (iv) the impact of ribbon development. Chapter 5 subsequently focuses on urban design features such as (i) attractiveness of place, (ii) building typologies, (iii) block scale densities sizes, and (iv) green spaces.

\section{Planning Concepts in Britain in the First Half of the 20th Century}

Cyprus was under British rule from 1878 but the public administration structure was built after 1925, when the island officially became a colony. Obviously, new ideas and practices present in Britain could not immediately be transferred to the colony and so they started influencing the Cyprus planning system only some years or decades later.

Local planning officers in the 1940s and 1950s, while they still had a pre-war mentality, were at the same time aware of post-war planning challenges in Britain. Britain was trying to come to terms with pre-war planning ideas set out by the 1932 Country and Town Planning Act and its relevant reports (Greed, 1991) while starting the post-war reconstruction of the country. The garden city was a keystone concept of British planning, which enabled harmonious urban living with green spaces and nature and also stressed the need for boundaries to city expansion. However, modern principles of movement and the need to boost the economy, especially after the recession of the 1930s, inspired a looser control over planning. The garden city was losing ground (Hardy, 1991, p. 120).

The main idea that the 1932 Act introduced was that planning should be applied everywhere and not within a specific boundary, leaving the areas at the periphery of the city uncontrolled or controlled in a limited way. This idea matured in the reality of Cypriot planning just after the fifties. Also present in the Act were ideas about the increasingly permissive powers of planning and the emphasis on the control of development, which was proposed for Cyprus at the end of fifties. The last main concept of the Act was the need for detailed approval of plans and planning regulations by the state, thereby restricting the powers of planning authorities. This last idea seems to have been bypassed by the Cyprus planning reports, which adopted a more effective approach, similar to the approach of the Town and Country Planning Act of 1947. The 1947 Act tried to correct some crucial weaknesses of the 1932 Act by, for instance, limiting the authority of the lower levels of local authorities (districts) to overprovide land for development, and creating stronger, larger bodies with less parochial attitudes. Another feature of the new act was the recognition that development rights and infrastructure are commons that can boost land development so the developer must return to the public a levy or betterment charge.

From a general point of view, pre-war planning in the UK had a more neoliberal flavour of laissez faire while post-war planning at its beginnings was more "positive" 
and rational, trying to balance between the market and society (Cullingworth \& Nadin, 2006, p. 10).

\section{The Planning Report of 1959}

Planning legislation in Cyprus was first approved in 1972, but only enacted in 1990 due to the military events of 1974: the Turkish invasion and the division of the island. The "Streets and Buildings Law" of the 1940s and its regulations first established restrictive planning principles, i.e. how to divide land into urban plots, how to design streets, where to build in terms of the water supply network etc. In 1949 the colonial government established the Department of Town Planning and Housing as the relevant public authority. From 1951 the Department worked on the preparation of the key Report, which aspired to lead to the first planning legislation on the island. The Planning Report consisted of a series of spatial indicators and descriptions, which related to problems and conflicts, and resulted in policies and legislation aimed at the remedying of uncontrolled practice.

The Report begins with a quote from Professor Antonio Kanayan (who was possibly a mentor of the author but who had no clear relation to Cyprus) underlining that public participation and democratic planning might not be effective in developing countries. There could be two reasons for beginning with this. The first might be to excuse the divergences of the report from the mainstream visions of planning in the UK, and the second might be to enhance public interventionism in order to enable the real estate free market and restrict speculation by local landowners.

After explaining why planning is necessary, in order to inform unfamiliar readers, the Report moves on to explain the land economics of Cyprus at the time. One of the first ideas expressed in the text is the need for Cyprus to become an attractive place for foreign investors. The first concern was the high value of urban land to a degree, which would prevent international businesses from investing in Cyprus. The high distribution of land ownership in almost every social group and cultural attitudes that encouraged the keeping of land prevented the development of a typical real estate free market. The Report (Morris, 1959) suggested that the discrepancy between suburban land values and the actual building demand made the island exempt from global real estate principles. In 1959, the island counted 1,675 ha of urban built land and 849 ha of unused plots served by the already constructed road network. The Report indicated that the roots of urban sprawl, uncontrolled city expansion, and land waste were related to land speculation and the absence of any kind of control by the state. Paradoxically "overparcellation" did not reduce plot values and certainly increased far beyond the rate of growth in the population. Since the distribution of private land included almost every social group, it was clear that speculation and real estate distortions benefitted a large proportion of the population (Morris, 1959). There was loose money in the market to invest and the only reliable investment seemed to be urban land. Additionally, there was no taxation on unbuilt land and there was, already in that period, a general feeling that cities would always continue to grow. These factors led to an artificial demand for urban land which was beyond the actual development needs.

The increase of private car ownership (it tripled between 1955 and 1957) and Building Regulation provisions boosted suburban development by introducing a "garden city-suburban cottage lifestyle" as the ideal. This was a relatively recent option for the lower and middle classes at this time (Ioannou, 2016). The Report underlined the high average housing floor space per person (compared to the international standards of that period), which had reached $18 \mathrm{~m}^{2}$ in 1959, and suggested a reduction to $13 \mathrm{~m}^{2}$ per person in order to conform to the British standards of that period (Morris, 1959, p. 10). This trend has continued into the contemporary period with an average floor space per person of $58 \mathrm{~m}^{2}$ in 2011 , the highest among the European Union states (Eurostat, 2014).

The Planning Report also pays significant attention to the "ribbon" development along the main roads leading out of towns which "stands out in the octopus-like shape of the spread" (Morris, 1959, p. 22). Ribbon development was seen as an important problem at the beginning of the 20th century in Britain, where the 1932 Act tried to confront this issue drastically. The Act included a general proposal for the creation of green belts around the main towns, the preservation of which again became crucial in post-war Britain. A green belt proposal was seen as totally inappropriate for Cyprus, and it is not mentioned at all in the Report. It is clear that the ownership distribution pattern and the development aspirations of a large part of the population would have been very negatively affected by the idea.

Another point in the Planning Report that links it to the planning debate in the UK and the 1947 Act relates to the problem of the inefficiency of small scale Local Communities as effective planners. The Report emphasized their inability to increase green space and update the image and quality of their residential areas, noting that the lack of interest in public open spaces was related to increased maintenance costs. The Report promoted tree planting in all streets, "to give shade to the cars and amenity to the citizens" (Morris, 1959, p. 23).

The Planning Report had a clear vision for the establishment of a new planning system in Cyprus, including the creation of planning authorities which could remove power from local politicians and municipalities, following the model of the British 1947 Act. A hierarchical planning system based on planning schemes (both general and detailed), publication, the right to objections, and modification through appeal to the Supreme Court was designed to produce reasonable and rational urban development which was, if possible, free of speculation. The central government could also control or manage the development pressures or weaknesses through Development Orders. 


\section{Economic Growth and Real Estate in the Post-Colonial Period. Contemporary Weaknesses of Suburban Development}

The British management of the Cyprus economy aimed at making the best of the country. As a colony Cyprus exported primary goods and imported industrial products from the UK. In 1960, the rural economy of the island showed symptoms of underdevelopment and fundamental structural weaknesses (Orphanides \& Syrighas, 2012). Cyprus gradually turned into a services sector economy over the next 30 years.

Actual economic growth started between 1961 and 1973. Construction has played a significant role in growth, driven by tourism, manufacture and, of course, the increasing housing needs and supply. The construction sector received high investment for infrastructure projects, residential units, rented offices, shops, and tourist accommodation (Orphanides \& Syrighas, 2012). In 1960, the percentage of the workforce employed in the construction industry was $20 \%$, while by 2010 this percentage had increased to $35 \%$ (Statistical Service, 2016). Real estate and construction are also important from the point of view of foreign investment. Strategies for attracting foreign investment for real estate and the construction industry were introduced as early as the 1950s (Morris, 1959). In 2009, 33\% of foreign investments were concentrated in the real estate sector, particularly the rental and business activities (33\%) (Orphanides \& Syrighas, 2012, p. 62). Domestic demand continued to expand, especially after 1974. Easy access to credit for property purchases and the relatively low mortgage rates encouraged many Cypriots to increase their investment in real estate (Orphanides \& Syrighas, 2012, p. 573).

Social welfare in Cyprus relies on the distribution of land ownership, the small scale of enterprises, and the strong family ties between people (DTPH [Department of Town Planning and Housing], 2007). There was no clear boundary between the "investor" and "society", and the absence of planning and rational development control helped this figure gain a status of social legitimacy. Until 2000, the main cause for the extended urban sprawl was the oligopolistic structure of the real estate market as opposed to the need for low-cost land and affordable housing (Constantinides, 2014). Owners did not frequently sell their property, while first-time buyers (e.g. young couples) preferred to build their houses on family land rather than purchase on the secondary market (Orphanides \& Syrighas, 2012, p. 574).

In 1959 the Planning Report had already stressed the urgent need for planning legislation. Despite this, the legislation was approved by parliament thirteen years later and only came into force in 1990 due to the irregular political conditions that followed.

(i) Participatory procedures: The Cypriot state followed Prof. Kanayan's advice in restricting participatory planning procedures almost until the accession to the EU in 2004. Planning focused more on making land use plans and planning zones with no transparency or accountability. Prior to 2004 the only access a citizen had to the planning process was through public hearings, appeals and applications notwithstanding the provisions of the development plans. The scheduling, chosen locations, and publicity actually prevented the public from participating instead of facilitating its active involvement. Limited participatory practices, for example a two-stage public consultation and unrestricted, transparent processes, have only been introduced over the last decade (Ministry of Interior, 2008).

(ii) City expansion and sprawl: Uncontrolled city expansion, "overparcellation", and sprawl were attributed to the absence of planning legislation (DTPH, 2007), one of the causes of the overprovision of development areas in the official land use plans. The provision of more and more development zones was not supported by any kind of population forecast or based on any other measured indicators. Parcellation is the process of constructing local road networks, subdividing agricultural land into residential plots, and disposing of them through the real estate market. In some cases, the sale of the land takes decades. In many districts, the presence of large numbers of vacant plots is very common. The high prices of land held in Development Areas have caused lower income groups to search for residential land at a distance from the city centre, again contributing to the urban sprawl.

The planning system has consistently failed to preserve the periphery of urban areas and the countryside, a need discussed in the UK during the 1930s and highlighted in 1959 by the Cyprus Planning Report. The Urban Guard Program (DTPH, 2007) showed that, almost two decades after the implementation of the Planning Law, new suburban areas were scattered, subdivided plots and isolated residential units. Land fragmentation, assisted by the strong legal protection of ownership, remained a substantial obstacle to detailed planning and the implementation of a plan. The power of small landowners was increased by their access to local politicians and public officials. Additionally, private vehicle ownership increased and the priority was to construct main road arteries from the city centre to the suburbs, which was accompanied by a downgrading of the importance given to public transport. This in turn contributed to the prevalence of private automobiles with negative consequences on road congestion (DTPH, 2007). The Report underlined the need to prioritise street design in order to support existing needs, instead of creating new development opportunities and speculation.

The layout of the new neighbourhoods is usually incomplete because owners of specific parcels have the rights to fragmented developments without even the preparation of a basic master plan. For many years the only priorities of layout design were to maximize profit for the landowner and facilitate the movement of cars. Public green space constitutes only $10-15 \%$ of every 
property larger than $2,000 \mathrm{~m}^{2}$. The absence of any kind of provisions for urban land consolidation has created scattered and dysfunctional pocket parks. The inadequacy of public open spaces (DTPH, 2007) and networks for providing safe and pleasant pedestrian movement is evident in all urban areas, and is linked to their lack of substantial size or any rational distribution and management of green spaces and equipment.

(iii) Taxation and betterment levy: The idea of taxation, a betterment levy, and the regulation of the free real estate market are not new concepts for Cyprus. They are not, of course, neoliberal ideas; instead, they fit the vision of a socially responsible state that merely through its actions (planning regulation and infrastructure construction) creates surplus value for private landowners. This surplus, if seen as a common resource, is unequally distributed in society because of the nature of planning. Therefore, the state legitimately expects a part of this profit in return. The Planning Report outlined this need and since then it has been highlighted in a number of planning documents (DTPH, 2011). Recently, a Ministry of Interior Report (2008) clearly suggested the application of such a levy but suspiciously no such action has been taken since then (Nanos, 2015).

(iv) Ribbon development: The Nicosia Local Plan notes that during the fifties, but mainly after 1960, the building plot ratio was rapidly increasing for the satel- lite settlements, attracting mainly the lower and middle classes (DTPH, 2011, p. 1.4.3). Over the following decades, the new socioeconomic conditions activated and prolonged a process of unplanned, spatially unstructured and uncontrolled ribbon development along the main road network. Ribbon development creates negative conditions that were already described in the 1959 Report. The absence of structured and properly equipped walkable neighbourhoods, the dominance of car usage, and the wider city structure encouraged ribbon development, especially for hosting services and commercial uses. In recent years, street widening, in order to increase the carrying capacity of roads and to enable private vehicle circulation, has affected the existing land use. Such designs, combined with periods of economic recession, reduced the vibrancy of these streets and turned them into ghost facades (Andreou, 2014).

\section{Neighbourhoods and Suburban Blocks: Building Typologies, Sizes, and Green Spaces}

(i) Neighbourhood layout: Pallouriotissa district is a suburb which developed early in close proximity to Nicosia's city centre. It expanded at the beginning of the 20th century around an old core of irregular urban fabric (See Figure 1). The suburban block layout uses some of the British mid-war design standards, of course in a local

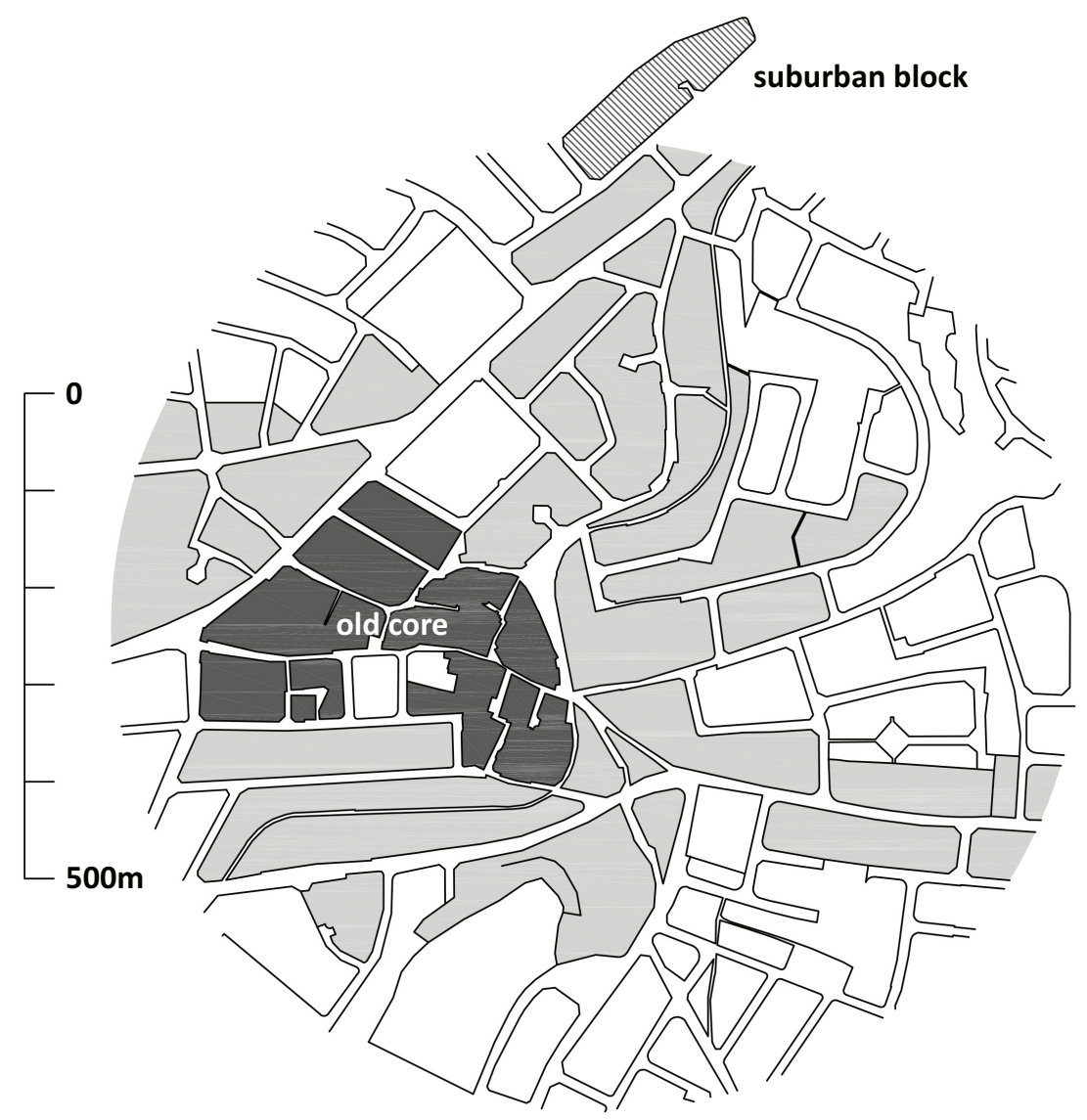

Figure 1. Pallouriotissa-Nicosia suburban development: old core (dark grey), early developed area-up to 1963 (light grey), case study block (hashed). 
interpretation, which facilitate vehicle movements and prevent pass-through traffic. The new neighbourhoods have no distinct design concept or any kind of general layout that was defined prior to their full realization. Neither are there any visible boundaries to the district, which expanded continuously in a patchy and additive manner throughout the decades. It is possible that any feature of functional neighbourhood design should be seen as a restriction to maximizing the number of urban plots for the benefit of landowners.

Since the beginning of the $20^{\text {th }}$ century, suburban development regulation has restricted the model of continuous frontage in the urban fabric, apart from in the traditional city centre cores, and has allowed only freestanding buildings in plots of a minimum size of around $520 \mathrm{~m}^{2}$. The only concept of suburban block design is the maximization of development plots in a given parcel configuration. No provision was made for public or green spaces and the design was characterized by the lack of a sense of orientation or any sense of neighbourhood structure. It is clear that the only concern is vehicle access to every plot, while walkability is lost from the outset of the implementation.

Plot division and land development provisions, both in this area and in general, allowed a large number of plots to lay dormant for a long time. As the distance from the core increased, empty and undeveloped plots increased and density decreased. Greater development rights and real estate demands over the last 25 years have generated dense areas within this early-developed suburbia (loannou, 2016). A typical plot of around $520 \mathrm{~m}^{2}$ has been the general standard for plot division all across the island for more than seventy years.

(ii) Building Typologies: The building typologies vary according to the period, both generally and specifically in the Pallouriotissa district. According to loannou (2016), three major building types can be observed:

- Prior to 1970: Free-standing single houses of about $150 \mathrm{~m}^{2}$, masonry units with timber roofs of an architectural style quite similar to the British colonial cottage, with approximately $70 \%$ of the plot left unbuilt and covered by soil and Mediterranean gardens. (Figure 2, top right)

- 1970 s to early 1990s: Modernist, concrete, flatroof versions of free-standing buildings of one to four residential units with a significantly larger footprint, increased hard surfaces for parking, and only around $10 \%$ of the plot covered by soil and greenery. (Figure 2, bottom right)

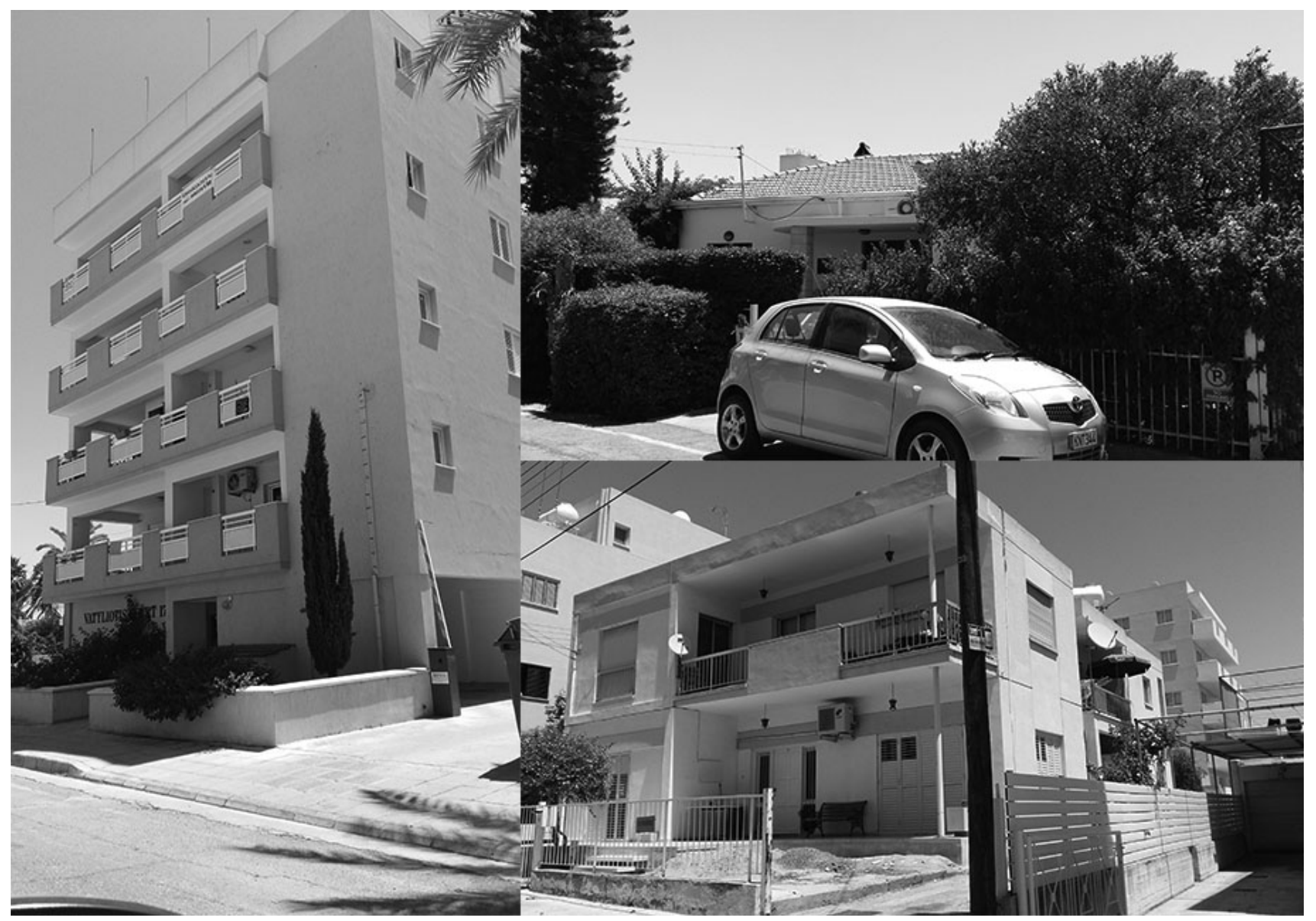

Figure 2. Suburban block images: Top right-prior to the 1970s; Bottom Right-1970s to early 1900s; Left-Mid-1990s until today. 
- Mid-1990s to today: Multi-storey blocks of flats on pilotis, with hard ground surfaces over its totality, usually for parking places. (Figure 2, left)

The suburban block illustrated here lies at the periphery of the urban expansion boundary of 1963. It is suitable as an illustration of a number of the issues discussed above. The shape of the plot division reveals that its original design was actually for two separate blocks, modified by the inclusion of a cul-de-sac and the suppression of a possible transversal street. It is obvious that this modification was undertaken in order to maximize the total number of plots. The northern part of the block was totally developed before 1963 while the southern part, as can be seen in the aerial photos archive in the land registry, had no access to the road network at that time. This area appears as a developed island in the middle of fields of grain. Even in this single block there was no idea of gradual expansion in continuity with the already developed urban boundary. Developments could move in any way inheritance or family issues suggested, thereby disrupting any sense of a compact or continuous fabric.

The analysed block area is approximately 1.5 ha and was partially developed in 1963. According to the 1959 estimation of floor area per person, the block was supposed to house 281 inhabitants with a net density of 187 inhabitants per ha, which today is considered sustainable (UN Habitat, 2013). Of course, these figures were hypothetical as the block was only partially built and the real inhabitant density in 1963 was 58 inhabitants per ha, which is low but similar to the densities of recently established suburbs on the outskirts of the city.

(iii) Densities and building processes: Today, it is estimated that the block houses 213 inhabitants, which gives a density of 143 inhabitants per ha. This density is again very close to global sustainability guidelines (UN Habitat, 2013) and of course close to but below the desired density when the block was initially developed in the 1950s. More than sixty years were necessary to approach the de- sired densities for which the city expanded. What would the real density be if all the plots had been developed according to the maximum building plot ratio permitted in the Local Plan? The total number of inhabitants would increase to 370 , which would give a density of 246 inhabitants per ha. It is certainly a sustainable size, but unusual. In this case local people would surely experience such densities as high. In such an instance, they would choose to move from the area, land values would be affected, and new social groups would move in, changing its status from a district with a mix of social classes to one of predominantly middle to lower classes.

This kind of transformation procedure is already emerging through gradual, plot-by-plot demolition and rebuilding. From a total number of 14 "cottage style" houses, two were demolished three and eight years ago, leaving their plots to be used as parking spaces while they await larger developments. Another four have been progressively demolished since the 1980s and replaced by newer buildings, and one has been partially demolished and modified (Figure 3). From this point of view, any kind of compactness or identity in this small group of flat-roof houses of the same age has been lost. It is quite obvious that the block has been continuously developed at least during the last six decades. The oldest and the newest buildings were built sixty years apart. There are no gaps, as plots continue to develop gradually, one every 3 to 5 years. Pallouriotissa district, and of course all similar cases, can be called an "early" suburb but it is not an "old" one. Plot developments are proceeding at the same rate as in new peripheral suburbs, where of course the percentage of empty, dormant plots is far above the $8 \%$ observed in this case.

Figure 4 shows that the height of the buildings varies from one to four floors and roof cover (not included) also varies. There are flat concrete slabs as well as wooden tiled roofs. In this broad sense, uniformity cannot be achieved, except in the similarity of plot size, which gives a common scale to almost all suburban areas in Cyprus.
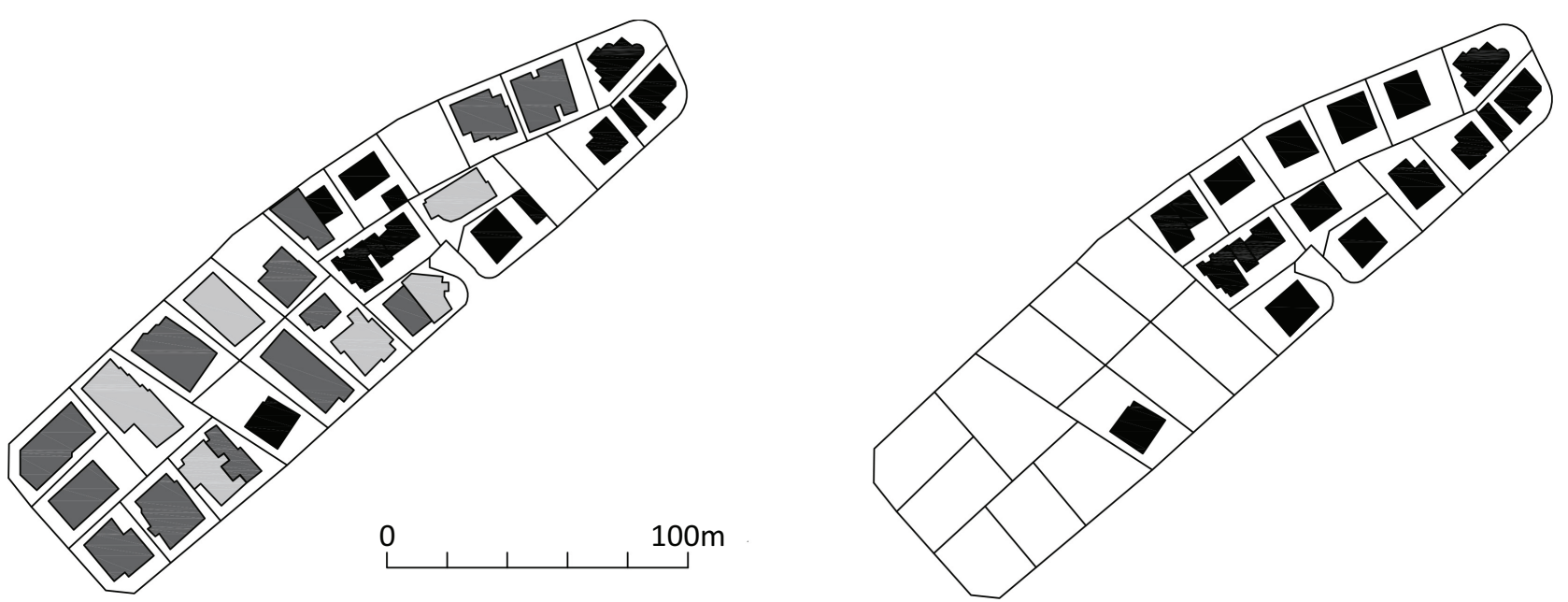

Figure 3. Left-Suburban block construction phases today: prior to 1963 (black), 1970s to early 1990s (grey), less than 20 years old (light grey). Right-Suburban block in 1963. 

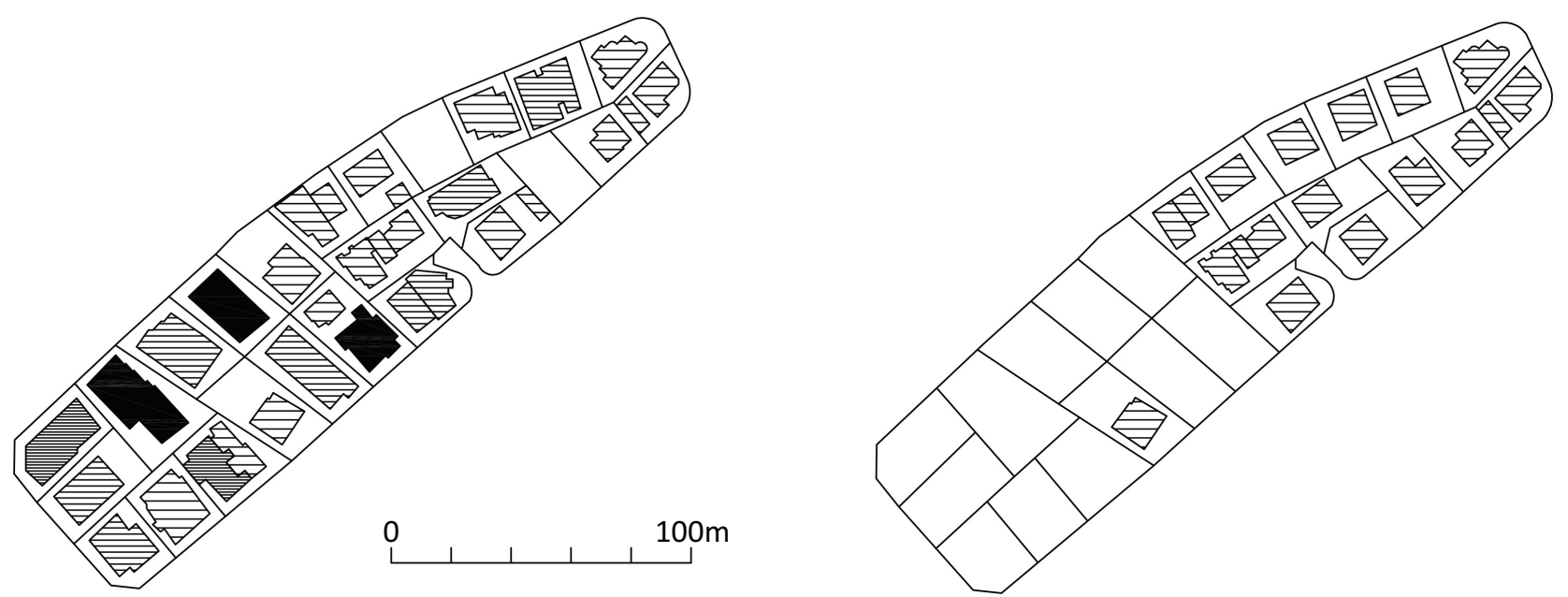

Figure 4. Suburban block heights-from lighter to darker hatch: 1 to 4 floors. Today (left), 1963 (right).

Neighbourhood identity is essential for building the idea of a community and sustainable living places (Gutiérrez, 2013). Character and identity are lacking in this case because of the slow rate of filling the empty plots in the block and the periodical changes in the building regulations on the same block (legal height and density), combined with the absence of design guidelines or restrictions. It is very difficult to distinguish any kind of neighbourhood character. The images in Figure 2 could have been taken from completely different areas but in fact they were all taken from the same suburban block.

(iv) Urban Green Spaces: Green space is a feature of urban development which has been generally neglected both by planning legislation and the reality of development. There is a lack of functional, shaded, properly equipped local green public spaces in most of the urban districts (DTPH, 2007). Early suburbs are provided with even fewer public green spaces, but at least at the beginning of their development they were full of Mediterranean orchards and flower gardens surrounding the freestanding housing units. Private gardens are an essential feature of suburban neighbourhoods, in terms of both their aesthetic and environmental value. Plot development models and new building typologies gradually limited the proportion of greenery and gardens in most of the suburban districts. The images in Figure 2 are indicative of the processes that decrease the quality of the neighbourhood and worsen living conditions. If the case study block were completely built in the pre-1970 typology, $60-70 \%$ of its area could be covered by unsealed soil and vegetation. Today this percentage, excluding the unbuilt plots, is around $25 \%$. There is no rule or regulation preserving this percentage, which could fall to $0 \%$ if further reconstruction occurs. Merely the transformation of the building in the bottom right image in Figure 2 into the one in the top left would constitute a severe alteration.

The framework for land development used prior to 1960 produced a neighbourhood typology that, despite its weaknesses (in particular the initiation of urban sprawl), created liveable conditions on its microscale.
The fact that the foundations of this model are of course unsustainable from today's perspective does not eliminate its positive features. Sometimes there is a conflict between compactness on one hand, and green spaces and a low scale on the other (Farr, 2011) but there are also development models trying to achieve both. The benefits of the early typology (scale, green space etc.) were not evaluated or protected by planning. Instead, the densification process of increasing the building ratio was only designed for speculation and not actually to increase compactness. It is clear that from a sustainability viewpoint, layout design, densities, character and identity, and finally green spaces have been negatively affected by the planning decisions of the past sixty years.

\section{Conclusions}

The aim of the paper was to increase understanding of the evolution of early suburbia in Cyprus. Planning and development control proved flexible in allowing a continuous transformation of their development features and character. This flexibility could have benefited the city if it had been targeted and allowed to completely transform a district according to urban development trends and the city's needs. An opportunity to use this flexibility to reduce city expansion and sprawl has been lost. Instead, a scattered-city model has been generated. In fact, the power of the local land market and the pressures from many individual owners, have formed a quasineoliberal laissez faire. As a result, overprovision of development land has become the key feature behind the failure of planning to maintain decent standards in living environments.

An assessment of densities on a macroscale has also been absent since the 1959 Report. Early suburban areas were developed in close proximity to the city centre. Initially the model of the "cottage style", car-oriented garden city was in line with the trends and style of that period. Planning failed to project the size of today's suburban development and city expansion, as well as to re- 
Table 1. Relation of the shortcomings of 1959 Report to contemporary planning and suburban development in Cyprus.

\begin{tabular}{|c|c|c|}
\hline Sustainability Indicators & 1959 Report & $\begin{array}{l}\text { Contemporary Planning and Urban } \\
\text { Development in Cyprus }\end{array}$ \\
\hline $\begin{array}{l}\text { Participatory and Democratic } \\
\text { Planning }\end{array}$ & $\begin{array}{l}\text { Centralized planning, less power to } \\
\text { communities }\end{array}$ & $\begin{array}{l}\text { Centralized planning, small steps to } \\
\text { transparency and open procedures after } 2008\end{array}$ \\
\hline City Expansion and Sprawl & $\begin{array}{l}\text { Problem highlighted, no specific } \\
\text { remedies suggested }\end{array}$ & $\begin{array}{l}\text { Problem highlighted, no specific remedies } \\
\text { suggested }\end{array}$ \\
\hline $\begin{array}{l}\text { Taxation and Betterment } \\
\text { Levy }\end{array}$ & $\begin{array}{l}\text { Problem highlighted, betterment } \\
\text { levy suggested }\end{array}$ & $\begin{array}{l}\text { Problem highlighted, no specific remedies } \\
\text { suggested }\end{array}$ \\
\hline $\begin{array}{l}\text { Commercial Streets Ribbon } \\
\text { Development }\end{array}$ & $\begin{array}{l}\text { Problem highlighted, no specific } \\
\text { remedies suggested }\end{array}$ & Consolidated through planning zones after 1990s \\
\hline Attractiveness of Place & $\begin{array}{l}\text { Specific observations made } \\
\text { regarding new developments }\end{array}$ & $\begin{array}{l}\text { Generic references. No actual policies proposed } \\
\text { with the exception of the historic/ preserved areas }\end{array}$ \\
\hline Building Typologies & No significant reference & $\begin{array}{l}\text { Policies and regulations to promote diversity in } \\
\text { building types }\end{array}$ \\
\hline Densities and Sizes & $\begin{array}{l}\text { Problem highlighted, no specific } \\
\text { remedies suggested }\end{array}$ & Not audited or assessed in any way \\
\hline Green Spaces & $\begin{array}{l}\text { Extensive highlights and proposals } \\
\text { for actions }\end{array}$ & $\begin{array}{l}\text { Generic references. No substantial provision of } \\
\text { green and public spaces for neighbourhoods }\end{array}$ \\
\hline
\end{tabular}

alize the central future location of these low-density areas. Flexibility to increase density and renew the building stock seems rational but it has been caused by speculative interests. Consequently, it has not been strategically applied in order to facilitate change for the city, but rather to maximize the benefits to owners and developers. Systematic urban audits and quantitative documentation might have been a tool for safeguarding the planning against these speculation powers. It was a legacy of the Report that was abandoned over time.

If character and identity can be seen as subjective, the reduction of green spaces, random densities, and spot densifications led to an unplanned and degraded city. It is obvious that, because of the expectations of consolidated land development, the use of public land, transportation, and social infrastructure are very hard to plan and provide on a long-term basis. Suburban developments in Cyprus are highly unsustainable, since urban commons-land and other spatial resources-are always used for the benefit of the developer, whether big or small, and not for the benefit of the local community. Table 1 proves that the guidelines or intentions of $1959 \mathrm{Re}-$ port were actually more sensitive and sustainable than the later evolution.

Planning documents from more recent periods have led to sprawl as well as the other main problems of specific land development in Cyprus, and to the lack of efficient planning legislation. Planning legislation and a complete planning system exist and have already been in place since 1990, but they do not seem to be efficient. Public Planning Authorities are well aware of both the shortfalls and the possible remedies. What seems to be missing is the political will to introduce firstly reason- able and then sustainable urban development. The key for motivating political will could be to transform microenterprises and micro-owners with their own "neoliberal" or "oligopolistic" interests into a society of common values. The flexibility of the early suburbs over time could still have the potential to achieve sustainable and compact neighbourhoods.

\section{Acknowledgements}

The paper is supported by field research material provided by the projects of $3^{\text {rd }}$-year students of Architecture at Frederick University, during the academic year 2015-2016.

\section{Conflict of Interests}

The author declares no conflict of interests.

\section{References}

Allmendinger, P. (2009). Planning theory. Hampshire: Palgrave.

Andreou, E. (2014, December 13). Tseri avenue residents protest against 'outdated' plans. Cyprus Mail.

Constantinides, G. (2014). Reasons for and consequences of urban sprawl (Working Paper). Retrieved from http://www.academia.edu/26597385/Reasons_for_ and_Consequences_of_Urban_Sprawl_Case_Study_ of_Nicosia

Cullingworth, B., \& Nadin, V. (2006). Town and country planning in the UK. Oxon: Routledge.

Drilling, M. (2013). Planning sustainable cities: Why envi- 
ronmental policy needs social policy. In I. Wallimann (Ed.), Environmental policy is social policy-Social policy is environmental policy (pp. 103-119). New York: Springer.

DTPH. (2007). URBANGUARD-Capacity building for enabling the incorporation of sustainability parameters in urban spatial development and planning policies and practices through the use of indicators in Cyprus. Retrieved from http://www.moi.gov.cy/moi/ urbanguard/urbanguard.nsf/dmlproject_en/dmlproj ect_en?OpenDocument

DTPH. (2011). Nicosia local plan. Nicosia: Ministry of Interior-Department of Town Planning and Housing. Eurostat.

(2014). Housing conditions. Retrieved from http:// ec.europa.eu/eurostat/statistics-explained/index.php /Housing_conditions

Farr, D. (2011). Sustainable urbanism: Urban design with nature. Boston: Wiley.

Gutiérrez, F. R. (2013). City, urbanism, social sustainability and the right to the city. In D. Henckel et al. (Eds.), Space-time design of the public city, urban and landscape perspectives (pp. 217-225). Dordrecht: Springer.

Hardy, D. (1991). From garden cities to new towns. Campaigning for town and country planning 1899-1946. Oxford: Alexandrine.

Harvey, D. (2001). Spaces of capital: Towards a critical geography. Oxon: Routledge.

Healy, P. (2010). Making Better Places-The Planning
Project in the Twenty-First Century Patsy. Basingstoke: Palgrave MacMillan.

Greed, C. (1993). Introducing town planning. London: Longman.

loannou, B. (2016). Town planning, development patterns and the reduction of private gardens in the suburbia of Cyprus. In Growing in Cities-COST-Action 1201 Urban Allotment Gardens in European Cities Conference. Basel: University of Applied Sciences and Arts Northwestern Switzerland.

Ministry of Interior. (2008). Revision report of the Minister of Interior on the Nicosia local plan. Nicosia: Ministry of Interior. (In Greek)

Morris, W. (1959). Planning report. Nicosia: Department of Planning and Housing.

Nanos, K. (2015, January 25). Bubble plans of four new cities. The mammoth ... eat Pafos. Politis, p. 1. (In Greek)

Orphanides, A., \& Syrighas, G. (2012). The Cyprus economy. Historical review, prospects, challenges. Nicosia: Central Bank of Cyprus.

Statistical Service. (2016). CYSTAT: Industry \& construction. Retrieved from http://www.mof.gov.cy/mof/ cystat/statistics.nsf/industry_construction_62main_ en/industry_construction_62main_en?OpenForm $\&$ sub $=2 \&$ sel $=1$

UN Habitat. (2013). Planning and design for sustainable urban mobility: Global report on human settlements 2013. Oxon: Routledge.

\section{About the Author}

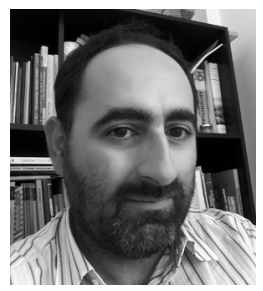

Byron Ioannou is an Assistant Professor of Urban Planning and Sustainable Built Environment at Frederick University. He also teaches at the Open University of Cyprus. He studied Architecture (Dip. Eng.) and Urban \& Regional Planning (MSc, PhD) at the National Technical University of Athens. He has also studied Planning Law (PG Cert) at Leeds Beckett University. His current research focuses on the environmental aspects of planning, density and sprawl, public space and urban green space, collaborative design and inclusive planning. 